\title{
Perspective of Competition Law on Partnership of Palm Oil Company and Nucleus Estate
}

\author{
Ningum Natasya Sirait ${ }^{1{ }^{*}}$ Rosmalinda $^{2}$, Mahmul Siregar ${ }^{3}$ \\ ${ }^{1,2,3}$ University Sumatera Utara \\ Email:ningrum@usu.ac.id,ningrum@gmail.com
}

\begin{abstract}
Partnership is important in a business including the oil palm plantation. As a form of cooperation in business circle, partnership should be exist either directly or indirectly. Moreover, it must be applied in some principles such as mutual need, trust, strengthening, and benefit. Partnership should involve all categories of enterpreneurs-Micro, Small and Medium Enterprises (MSME) actors and large businesses. Article 1 paragraph 13 of Law No. 20/2008 discusses on the Partnership. This topic is interesting due to the presence of the Business Competition Supervisory Commission (Komisi Pengawasan Persaingan Usaha/KPPU) in the supervision of partnerships. This research raises a question, namely what is the legal issue concerning the role of KPPU in supervising the Partnership between Smallholders and Palm Oil Companies. This study analyzes laws and regulations such as (1) Law No. 20/2008 concerning MSME (2), Government Regulation No. 7/2021 concerning Ease, Protection, and Empowerment of Cooperatives and Micro, Small, and Medium Enterprises. Medium. (3) Law No. 39/2014 concerning Plantations, and (4) Law No 11/2020 concerning Job Creation. The researcher also interviewed officer(s) of regional KPPU 1 and ATR-BPN in 4 districts in North Sumatra. The study found that the existence of the KPPU which has function(s) to oversee monopolistic practices and unfair business competition, also oversees the implementation of partnerships. This is regulated in PP 17/2013 which has been revoked by PP No. 7/2021. KPPU conducts supervision in coordination with related institutions such as ATR-BPN in the Plasma core partnership pattern. As conclusion, the existence of the KPPU in supervising the implementation of the Partnership after the fulfillment of the $20 \%$ partnership requirement to obtain a HGU permit from an oil palm company is a gap for unfair business competition. As for suggestions, KPPU should conduct intensive coordination with ATR BPN to optimize existing plasma core partnerships.
\end{abstract}

\section{Keywords: Legal, Partnership, Palm Oil, NSE Business, Competition}

\section{INTRODUCTION}

Plantation commodities are the mainstay of national income and one of the largest contributors to foreign exchange in Indonesia, which can be seen from the export value of plantation commodities. In the midst of the development and development of various conventional commodities, there is one commodity that until the late 1970s was only cultivated by large plantations, namely oil palm. ${ }^{1}$

Oil palm plantation commodities are one of the main targets for developing and improving the investment climate in order to boost the national economy. Oil palm

1 Badrun. M, Lintasan 30 Tahun Pengembangan Kelapa Sawit, (Jakarta: Direktorat Jenderal Perkebunan Kementerian Pertanian Republik Indonesia, 2010), hal. 2. plantations in Indonesia are growing rapidly, especially smallholder plantations. Additionally, oil palm is a top priority commodity to be seeded. It must be considered in term of the role of the Government by the nucleus estate and smallholders pattern. ${ }^{2}$

The government's intervention in the economic sector is directed towards the realization of people's welfare based on Pancasila and UUD 1945-Basic constitution as stated in Article 33 Paragraph (4) which stipulates that The implementation of the national economy is based on several principles, namely: (1) economic democracy with the principle of togetherness,

${ }^{2}$ http://p2k.unkris.ac.id/id3/30652962/Perkebun anIntiRakyat 54741 p2kunkris.html\#: :text=Perkebuna n\%20Inti\%20Rakyat\%20(PIR)\%20adalah,saling\%20me nguntungkan $\% 2 \mathrm{C} \% 20$ utuh $\% 20$ dan $\% 20$ berkelanjutan, akses 30 September 2021. 
(2) efficiency, (3) fairness, (4) sustainability, (5) environmental insight, (6) independence, and (6) maintaining balance progress \& national economic unity. ${ }^{3}$

The palm oil industry in Indonesia is using an approach that prioritizes a balancing among environmental, social, and economic. This is in accordance with the commitment of the Government of Indonesia in implementing sustainable development, which has been specifically regulated in RPJM (Rencana Pembangunan Jangka Menengah Nationalthe National Development Plan of Medium Term) 20202024. Sustainable development has been defined as one aspect of mainstreaming, which aims to provide access to equitable and inclusive development, thereby protecting the environment, so as to maintain and improve the quality of life. Through this approach, the Government of Indonesia believes that sustainable palm oil development contributes significantly to the achievement of the Global Sustainable Development Goals which known as SDGs. ${ }^{4}$

The government also remains committed to replanting 180,000 hectares of oil palm plantations owned by smallholders by 2021. This is intended to increase the number of productivity of oil palm plantations, especially at the level of smallholders. ${ }^{5}$

The largest palm oil plantations are in 26 provinces in Indonesia where Sumatra Island has the largest oil palm plantation area reaching 7,944,520 hectares, followed by Kalimantan Island with an area of $5,820,406$ hectares. Most of the palm oil in Indonesia is cultivated by large private companies (PBS) which is $54.94 \%$ or an area of $7,942,335$ hectares, People's Plantation (PR) occupies the second position in its contribution to the total area of Indonesian oil palm plantations which is 5,896,755 hectares or $40.79 \%$ and State Large Enterprises (PBN) at $4.27 \%$ or 617,501 hectares. ${ }^{6}$

Data of Plantation-Directorate General of Plantations shows that total area of oil palm plantations in Indonesia based on preliminary figures in 2020 is $14,858,300$ hectares, consisting of People's Plantations $6,003,764$ hectares, State Large Plantations (PBN) 569,166 hectares, and Large Private Plantations ( PBS) $8,285,370$ hectares. Meanwhile, based on the estimated 2021 figures, the area of oil palm plantations is

$$
\begin{aligned}
& { }_{4}^{3} \text { UUD 1945, Pasal } 33 \text { Ayat (4). } \\
& \text { Siaran }
\end{aligned}
$$

Pers

HM.4.6/82/SET.M.EKON.3/04/2021 Kementerian Koordinator Bidang Perekonomian Republik Indonesia, Industri Kelapa Sawit Indonesia: Menjaga Keseimbangan Aspek Sosial, Ekonomi, dan Lingkungan, Jakarta, 22 April 2021.

$$
\begin{aligned}
& { }^{5} \text { Ibid. } \\
& { }^{6} \text { Ibid. }
\end{aligned}
$$

15,081,021 hectares, consisting of People's Plantations 6,084,126 hectares, State Large Plantations (PBN) 579,664 hectares, and Large Private Plantations (PBS) $8,417,232$ hectares. $^{7}$

As the largest plantation commodity, in the implementation of its partnerships, oil palm commodities experience many challenges that require the implementation of partnership supervision. A study concerning the adaptation strategy in the communication behaviour is applied by nucleus estate people stated there is a different culture in communication behaviour big estate (nucleus estate) and small holders (plasma farmer). ${ }^{8}$ It is big estate is oriented to modern capitalism (nucleus estate), and another side small holders (plasma farmer) is oriented to the traditional pre-capitalism. ${ }^{9}$ Other study found that communication is one of the five success factors in addition to cooperation, trust, commitment, and value relationships. ${ }^{10}$

This study aims to see how the rules regarding the role of KPPU in supervising the partnership between nucleus estate farmers and palm oil companies.

\section{METHOD}

A normative legal research method was used in this study. Furthermore, it reviewed some literatures or known as secondary legal materials. These materials support the primary legal sources in the form of statutory regulations. This legal research approach use both statutory and a conceptual approach in applying to the research question.

\section{RESULTS AND DISCUSSION}

Imron Zahri stated that the nucleus-plasma partnership in the oil palm PIR pattern has an impact on the household economy of plasma farmers; (a) the farmer's household income was initially low, then increased at the end of the cropping cycle to be low again. As a consequence, the farmer's life depending on the productivity of the plasma plantation and (b) the amount of free time from the plasma farmer's household labor has the potential for subtle unemployment and a poor work ethic. ${ }^{11}$ For this reason, several ideas are

\section{${ }^{7}$ Ibid.}

${ }^{8}$ Rejeki, S., \& Ninik, M. C. Perbedaan Budaya Dan Adaptasi Antarbudaya Dalam Relasi Kemitraan Inti-Plasma. Jurnal Ilmu Komunikasi, 4(2), 101738

$$
{ }^{9} \text { Ibid }{ }^{10} \text { Ardiansyah, R., \& Aulawi, H. (2019). }
$$

Identifikasi Faktor-Faktor Kunci Keberhasilan Pola Kemitraan Inti Plasma. Jurnal Kalibrasi, 17(2), 43-51.

${ }^{11}$ Zahri, Imron (2013), Gagasan Mengatasi Masalah Ekonomi Rumah Tangga Petani Dalam Kemitraan Inti-Plasma Pola Pir Kelapa Sawit. In: 
offered as solutions, such as the development of an integrated partnership pattern, namely farmers doing business on-farm and developing smallholder shareholders in the processing industry, developing business diversification based on oil palm plantations such as animal husbandry, home industry, increasing investment and saving activities, developing credit schemes for rejuvenation of oil palm plantations etc. ${ }^{12}$

\subsection{Rules of Partnerships in Plantation Business}

The oil palm plantation business partnership started since the government developed Smallholder Palm Oil Plantation by the Plasma Core Pattern known as the People's Core Company Pattern (PIR Pattern) in the 1980 s and finally in the 2000s the Government developed the Community Garden Development Facilitation Pattern $20 \%$ (FPKM). ${ }^{13}$

Oil palm plantation business partnerships have been regulated in several laws and regulations both generally and specifically. According to Article 1 No. 13 of Law No. 20/2008, hereinafter abbreviated as the UMKM Law. As stated above, as a cooperation in business circle either directly or indirectly, partnership must be conducted on the basis of the principle of mutual need, trust, strengthening and profitable business involving Micro, SMEs with Large Enterprises. ${ }^{14}$

Furthermore, according to Article 1 number 1 of PP Number 44/1997 concerning Partnerships which define that partnerships means business cooperation among entrepreneurs including Small, Medium and Large Enterprises. It is needed to emphases that the relationship must use a guidance which based on the principle of mutual need, mutual strengthening and mutual benefit. ${ }^{15}$

Plantation partnerships are specifically mentioned in Article 57 Paragraph (1) of Law No. 39/2014 concerning Plantations, namely to empower Plantation Businesses, Plantation Companies conduct Plantation Business partnerships that are mutually beneficial, respect each other, are mutually accountable, and

Prosiding Seminar Nasional Perhepi Kemitraan Dalam Pengembangan Agribisnis Berbasis Sumberdaya Lokal. Perhimpunan Ekonomi Pertanian Indonesia (PERHEPI), 2013, Palembang, 15 April 2013, pp. 36-41. ISBN 978979-8420-13-9.

${ }^{12}$ Ibid

13 Ermanto Fahamsyah, 2021, Dua Dekade Penegakan Hukum Persaingan: Perdebatan dan Isu yang Belum Terselesaikan, (Jakarta: Komisi Pengawas Persaingan Usaha), hal. 535.

${ }^{14}$ UU No. 20/2008 tentang Usaha Mikro, Kecil dan Menengah, Pasal 1 angka 13.

${ }^{15}$ PP No. 44/1997 tentang Kemitraan, Pasal 1 angka 1 . strengthen and mutually dependence on Planters, employees, and the community around the Plantation. ${ }^{16}$

The important point of business partnerships is emphasized in Article 7 Paragraph (1) of Law no. 20/2008 concerning MSMEs which states the business climate developed by the National and local Governments refer to laws and regulations and policies with the following aspects: a. funding; b. facilities and infrastructure; c. business information; d. partnership; e. business license; f. business opportunities; g. trade promotion; and lastly is institutional support". ${ }^{17}$ Due to the importance of business partnerships to foster a business climate, the central government and local governments have a strategic role in the policy of making laws and regulations that encourage the implementation of business partnerships.

\subsection{Partnership Pattern in Plantation Business}

The Partnership Pattern is one form that is resolved to integrate plantation crop cultivation with plantation product processing businesses.

Partnerships can be implemented in a number of patterns. As regulated in Article 87 number 5 of Law No. 11/2020 concerning Job Creation Act (amending the provisions of Article 26 of the MSME Law), it is stated that partnerships can be implemented, among others with the following pattern: 1) Plasma Core Pattern; 2) Subcontracting Pattern; 3) Franchise Pattern; 4) General Trading Patterns; 5) Distribution and Agency Patterns; 6) Supply chain pattern; and 7) Other forms of partnership. ${ }^{18}$

Partnerships in plantation businesses generally use the nucleus Pattern. With regard to the partnership pattern, MoA No. 26/2007 stipulates that the processing partnership is carried out in writing in the form of an agreement containing rights and obligations, business development and development, funding, timeframe and dispute resolution signed by both parties with the knowledge of the Regent/Mayor. The minimum term of the processing partnership agreement is for a period of 3 (three) years. ${ }^{19}$

\footnotetext{
${ }^{16}$ UU No. 39/2014 tentang Perkebunan Pasal 57 Ayat (1)

${ }^{17}$ UU No. 20/2008 tentang UMKM, Pasal 7 Ayat (1). 87 Angka 5

${ }^{18}$ UU No. 11/2020 Tentang Cipta Kerja, Pasal

19 Komisi Pengawas Persaingan Usaha, Evaluasi Kebijakan Perkebunan Kelapa Sawit, hal. 23, dilihat pada http://web1.kppu.go.id/wpcontent/uploads/2020/03/Position-Paper-Sawit.pdf , akses 30 September 2021.
} 


\subsection{Business Competition Supervisory Commission (KPPU) as a Partnership Supervisory Agency}

In the implementation of a partnership agreement, it is a must to prioritize the equality and a balanced legal position between the parties. It is also a must for each party to comply with the basic principle of independence of MSME. A partnership should not place a party being sub-ordinate of dependent actor for others. $^{20}$

Often, there are indications that the agreement between the nucleus and plasma companies is not in accordance with the principle of freedom of contract between the company and the community who have the same legal standing. By-law, an agreement should provide freedom for the community either make an agreement or not. There should not neither any conflict with public order nor morality. ${ }^{21}$

To realize a fair pattern of cooperation, the agenda that should not be forgotten is to provide education to MSME actors to understand the importance of partnership agreements being made in written form and to understand the position of the parties that must be balanced in the partnership agreement. It turns out that a lot of things there are very exploitative. The point is to use MSMEs as a market, not a partner. SMEs are used as tools for their business interests. ${ }^{22}$

The challenges and concrete problems faced by Indonesian palm oil include several issues, namely: a. business partnership; b. trade and supply of oil palm fresh fruit bunches (FFB); c. land; d. plantation business legality; e. rejuvenation of smallholders' palm oil plantations; f. demands for sustainable palm oil (ISPO and RSPO); g. oil palm planter institutions; h. status and existence of palm oil mills (PKS) without plantations; i. collection of funds for oil palm plantations and their allocation; j. basic data on oil palm plantations; $\mathrm{k}$. direct/real contribution to the provincial government and/or district government in their APBD; 1. moratorium on permits for oil palm plantations; and $\mathrm{M}$. green fuel/biodiesel program. ${ }^{23}$

${ }^{20}$ https://kppu.go.id/pengawasan-kemitraan/ , akses 30 September 2021.

${ }^{21}$ Paul Scholten di dalam JJ. H. Bruggink, Refleksi Tentang Hukum (alih bahasa oleh Arief Sidharta), (Bandung: Cipta Aditya Bakti, 1996), hal. 13.

${ }^{22}$ Wahyu Kuncoro SN, Urgensi Pengawasan Kemitraan Pelaku Usaha dilihat pada https://kppu.go.id/wp-content/uploads/2020/12/Juara-3Umum-Wahyu-Kuncoro.pdf, akses pada 20 September 2021.

${ }^{23}$ Ermanto Fahamsyah, 2021, Dua Dekade Penegakan Hukum Persaingan: Perdebatan dan Isu
In facing these challenges, synergy between stakeholders is needed to be monitored in order to create a healthy business climate in the palm oil plantation sector. Article 7 Paragraph (1) letter d and Paragraph (2) of Law No. 20/2008 concerning MSMEs mentions that both national and local government must provide a business atmosphere by providing laws and policies in the aspects of partnership.

Furthermore, Article 11 letters $\mathrm{f}$ and g state that the purpose of the partnership aspect aims to encourage the formation of a fair play market structure. It ensures the growth of healthy business competition and protects consumers. Furthermore, the partnership prevents monopoly and business concentration by certain individuals or groups that are detrimental to MSME.

The quo law states that the implementation of partnerships is supervised in an orderly and regular manner by an institution. This institution was established and tasked with supervising business competition on the laws and regulations. This is stated in the provisions of Article 36 Paragraph (2).

Thus, PP No. 17/2013 on the Implementation of Law no. 20/2008 concerning MSMEs, starting from article 10 to article 35, regulates the Partnership, the Role of Government and Local Government in Partnership and Partnership Supervision. However, this rule was revoked with the issuance of PP No. 7/2021 concerning Ease, Protection, and Empowerment of Cooperatives and MSME which are derivatives or implementing regulations of Law No. 11/2020 concerning Job Creation Act.

The existence of the words "supervising partnership" and "supervising business competition" raises the question of who will be given the authority to supervise the partnership. This was answered by the mention of the Business Competition Supervisory Commission (KPPU) as a partnership supervisory agency explicitly in Article 119 Paragraph (1) of PP No. 7/2021 which states that:

The Business Competition Supervisory Commission shall supervise the implementation of the partnership which mentioned in Article 104 paragraph (1) and (2) in accordance with the provisions of the legislation.

In supervising partnerships, KPPU is asked to coordinate with relevant agencies and evaluation of partnerships can be carried out jointly between related Ministries/Non-Ministerial Government Agencies. KPPU is also given the authority to formulate a regulation on supervision procedures through a KPPU Regulation or a Commission Regulation, KPPU can also impose administrative sanctions on business actors who violate business partnerships.

yang Belum Terselesaikan, (Jakarta: Komisi Pengawas Persaingan Usaha), hal. 538. 
KPPU enforces Commission Regulation Number 4/ 2019 concerning Procedures for Supervision and Handling of Partnership Cases since October 17, 2019, namely since the regulation was promulgated by the Ministry of Law and Human Rights through the State Gazette Number 1212/2019. The regulation contains various provisions in the process of handling cases of Partnership supervision by KPPU. This regulation is the implementation of Law No. 20/2008 concerning Micro, Small and Medium Enterprises (MSMEs) and PP No. $17 / 2013$ concerning the Implementation of Law Number 20 of 2008 concerning SMEs (PP 17/2013). This Commission Regulation contains several matters which include the regulation of the authority of the partnership, not only from the side of supervision but also from the side of law enforcement.

The entry of KPPU to oversee plantation partnerships based on the authority given by PP No. $7 / 2021$, namely in the context of overseeing the nucleusplasma partnership pattern. In addition, indications of unfair business competition in processing, distributing, and/or marketing plantation products as mentioned in Article 77 of Law Npo. 39/2014 concerning Plantations can also be a gap that an institution that is oriented towards monitoring business competition is needed to oversee plantation activities.

According to the system of constitution in Indonesia, KPPU is a state auxiliary organ ${ }^{24} \mathrm{KPPU}$ has the authority based on the Business Competition Law to enforce the business competition law.

The definition of KPPU according to the Business Competition Law Article 1 number 18 mentions that as a commission, KPPU has the role of supervising business actors in operating their business. The roles of KPPU to ensure that business actors would not conduct monopolies and/or unfair business competition.

Apart from being an independent institution that is free of any interventions from government or other parties, KPPU is an institution that has a dual tasks. These are to create order in business competition and play a role in creating and maintaining a conducive environment and competition climate. ${ }^{25}$

The addition of KPPU's duties in supervising partnerships shows the existence and importance of the business competition supervisory authority in Indonesia. To realize a fair partnership, there should be a balanced

${ }^{24}$ Budi L. Kagramanto, Implementasi UU No. 5 Tahun 1999 Oleh KPPU, Jurnal Ilmu Hukum Yustisia, Vol, No, 2007, hal. 2.

${ }^{25}$ Jimly Asshidiqie dalam Andi Fami Lubis, dkk, 2009, Hukum Persaingan Usaha: Antara Teks dan Konteks, Komisi Pengawas Persaingan Usaha, Jakarta, hal. 313. position between large and small business actors as stated in the partnership agreement. ${ }^{26}$

\subsection{Supervision of Land Provision for Plasma in the Acquisition of $\mathrm{HGU}$}

KPPU supervises the implementation of Partnership between large business actors and MSMEs and between medium business actors and micro and small businesses. There are nine partnership patterns supervised by KPPU, namely nucleus-plasma, subcontracting, franchising, general trading, distribution and agency, profit sharing, operational cooperation, joint ventures, outsourcing, and other forms of partnership.

In the implementation of the various Partnership patterns, (i) large businesses are prohibited to have and and/or control their partners either micro, small, and/or medium business; and (ii) medium businesses are prohibited to have and /or control micro and/or smallscale business who being their partners. These two forms of prohibition are the object of KPPU's supervision. The prohibition of this kind of partnership are mentioned in Article 35 of Law no. 20/2008 concerning SMEs.

The Business Competition Supervisory Commission (KPPU) has determined that fines for business competition cases reached $\mathrm{Rp} 35.9$ billion throughout $2020 .^{27}$

In 2020, until the fourth week of December 2020 , KPPU handled 36 (thirty six) cases. Seventeen out of 36 cases are business competition violations, while 11 (eleven) are cases of delays in notification of mergers and acquisitions and 8 (eight) cases of violations of partnership implementation. From the number of cases, 15 (fifteen) case decisions have been made. ${ }^{28}$

The KPPU also pays serious attention to the partnership aspect of micro, small and medium enterprises. For 2020, there have been 15 (fifteen) reports of alleged partnership violations that have been submitted to KPPU. Eleven of them have been followed up by Investigation or Examination, of which 8 (eight) have entered the Case or Preliminary Examination Stage 2. Four of these cases have been given a Warning Letter/SP (both SP1 and SP2) by KPPU. Most cases of alleged violation of partnerships handled by KPPU are

26 https://kppu.go.id/blog/2020/11/peran-kppudalam-pengawasan-kemitraan-2/ , akses 30 September 2021

${ }^{27}$ Yohana Artha Uly

https://money.kompas.com/read/2020/12/30/213800626 /2020-kppu-sumbang-penerimaan-negara-rp-35-9miliar-dari-kasus-persaingan-usaha?page=all, akses pada 30 September 2021

${ }^{28}$ Catatan Kinerja KPPU di Tahun 2020 https://kppu.go.id/blog/2020/12/catatan-kinerja-kppu-ditahun-2020/ 
core plasma partnerships in the plantation, profitsharing, or distribution/agency sectors. ${ }^{29}$

The obligation to provide plasma plantations is also one of the requirements for obtaining land rights in the form of HGU (Hak Guna Usaha-Cultivation Rights) by the Company. Article 58 Paragraph 1 of Law no. $39 / 2014$ concerning Plantations mentioned related to the obligation of the plantation company which has cultivation permit are required to facilitate the development of community plantations minimalized $20 \%$ (twenty percent) of the total plantation area which managed by plantation companies." 30

Furthermore, it is stated in BPN No. 7/2017 concerning Regulations and Procedures for Establishing Cultivation Rights Article 40 Paragraph 1 letter k; Facilitating the development of community plantation at least $20 \%$ (twenty percent) of the plantation area is the obligations of the HGU Holder. This activity is a form of partnership (plasma) for the surrounding community of the plantation area in accordance with a business activity permit from the authorized technical agency. This is intended for the legal needs of entity's rights holders. ${ }^{31}$

Furthermore, Article 41 Paragraph 1 explains that The obligation to facilitate the development of community gardens by the plantation company is $20 \%$ of the total land area requested for HGU. Furthermore, this duty is only apply for the first HGU applicant with an area of $250 \mathrm{Ha}$ (two hundred and fifty hectares) or more. $^{32}$

Furthermore, in order to confirm the guaranteed supply of raw materials for plantation product processing industries, the Minister of Agriculture through legalized regulation No.26/Permentan/OT.140/2/2007 concerning Guidelines for Plantation Business Licensing in Article 10 regulates the necessity for palm oil processing industry businesses. meet at least $20 \%$ of their raw material needs from their own garden. ${ }^{33}$

Based on this provision, Article 11 states that companies holding IUP-B are required to develop
${ }^{29}$ Ibid.
${ }^{30}$ UU No. 39/2014 Tentang Perkebunan, Pasal 58 Ayat (1).

${ }^{31}$ Peraturan Menteri Agraria dan Tata Ruang/ Kepala BPN Nomor 7/2017 tentang Pengaturan dan Tata Cara Penetapan Hak Guna Usaha, Pasal 40 Ayat 1 huruf $\mathrm{k}$.

${ }^{32}$ Ibid.,Pasal 41.

${ }^{33}$ Komisi Pengawas Persaingan Usaha, Evaluasi Kebijakan Perkebunan Kelapa Sawit, hal. 21, dilihat pada http://web1.kppu.go.id/wpcontent/uploads/2020/03/Position-Paper-Sawit.pdf, akses 30 September 2021. plantations for the community at least 20\% (twenty percent) of the total area cultivated by the company.

The existence of a regulation regarding the obligation to facilitate the development of community gardens in the vicinity of at least $20 \%$ (twenty percent) of the total area of the plantations cultivated by the Plantation Company above contains a legal ratio or the basis for consideration that the area owned by the plantation company is in the form of Hak Guna The business and results from plantation activities are not only controlled and enjoyed by plantation companies.

KPPU's Commissioner, Guntur, observed that there are potential violations related to the provision of allocating 20 percent of the total land use rights (HGU) for plasma plantations or partnerships that can be utilized by surrounding communities in the plantation sector.

This makes the allotment of $20 \%$ of land as a requirement for obtaining $\mathrm{HGU}$ also an object of supervision by the Business Competition Supervisory Commission.

Based on the description above, it is concluded that the partnership supervision function is under the authority of the Business Competition Supervisory Commission in accordance with Article 119 Paragraph (1) PP No. 7/2021 concerning Ease, Protection, and Empowerment of Cooperatives and MSME. This regulation is an implementing regulation of Law No. 11/2020 concerning Job Creation. The involvement of KPPU in supervising plantation partnerships by conducting supervision with a nucleus-plasma partnership pattern.

\section{CONCLUSION}

The Partnership Policy between Smallholders and Companies is regulated in several regulations in Indonesia, including Law no. 20 of 2008 concerning SMEs, Law no. 39 of 2014 concerning Plantations, and Government Regulation No. 44 of 1997 concerning Partnerships.

The Partnership Pattern in the Plantation Business Partnership is the Plasma Core Pattern

The role of KPPU in partnership supervision is stated in Article 119 of PP. 7 of 2021 concerning Ease, Protection, and Empowerment of Cooperatives and Micro, Small and Medium Enterprises

Smallholder partnerships with oil palm companies are carried out in the form of plasma nucleus which is required to be present as much as $20 \%$ when the HGU permit is requested by the palm oil company. 


\section{ACKNOWLEDGMENTS}

We would like to thank the Research and Service Institute of Universitas Sumatera Utara who supported the authors to implement research program through TALENTA Universitas Sumatera Utara research scheme of Fiscal Year 2021 based on the Rector Letter Number: ..../UN5.1.R/PPM/2021 Dated on 16 June 2021.

\section{REFERENCES}

[1] M. Badrun, Lintasan 30 Tahun Pengembangan Kelapa Sawit, (Jakarta: Direktorat Jenderal Perkebunan Kementerian Pertanian Republik Indonesia, 2010)

[2] https://www.google.co.id/search?hl=id\&q=perkeb unan + inti + rakyat\&meta $=\& g w s \_r d=$ sslakses $\quad 30$ September 2021.

[3] Undang- Undang Dasar 1945, Pasal 33 Ayat (4).

[4] Penyiaran Pers HM.4.6/82/SET.M.EKON.3/04/2021 Kementerian Koordinator Bidang Perekonomian Republik Indonesia, Industri Kelapa Sawit Indonesia: Menjaga Keseimbangan Aspek Sosial, Ekonomi, dan Lingkungan, Jakarta, 22 April 2021.

[5] Direktorat Jenderal Perkebunan-Kementerian Pertanian, Statistik Perkebunan Unggulan Nasinal 2019-2021 Kelapa Sawit, (Jakarta: Direktorat Jenderal Perkebunan, 2020), hal. 1.

[6] Ermanto Fahamsyah, 2021, Dua Dekade Penegakan Hukum Persaingan: Perdebatan dan Isu yang Belum Terselesaikan, (Jakarta: Komisi Pengawas Persaingan Usaha), hal. 535.

[7] Undang-Undang Nomor 20 Tahun 2008 tentang Usaha Mikro, Kecil dan Menengah, Pasal 1 angka 13.

[8] Peraturan Pemerintah Nomor 44 Tahun 1997 tentang Kemitraan, Pasal 1 angka 1.

[9] Undang-Undang Nomor 39 Tahun 2014 tentang Perkebunan Pasal 57 Ayat (1).

[10] UU No. 20 Tahun 2008 tentang UMKM, Pasal 7 Ayat (1).

[11] Undang-Undang No. 11 Tahun 2020 Tentang Cipta Kerja, Pasal 87 Angka 5

[12] Komisi Pengawas Persaingan Usaha, Evaluasi Kebijakan Perkebunan Kelapa Sawit, hal. 23, dilihat pada http://web1.kppu.go.id/wpcontent/uploads/2020/03/Position-Paper-Sawit.pdf , akses 30 September 2021.
[13] https://kppu.go.id/pengawasan-kemitraan/ , akses 30 September 2021.

[14] Paul Scholten di dalam JJ. H. Bruggink, Refleksi Tentang Hukum (alih bahasa oleh Arief Sidharta), (Bandung: Cipta Aditya Bakti, 1996), hal. 13.

[15] Wahyu Kuncoro SN, Urgensi Pengawasan Kemitraan Pelaku Usaha dilihat pada https://kppu.go.id/wpcontent/uploads/2020/12/Juara-3-Umum-WahyuKuncoro.pdf, akses pada 20 September 2021.

[16] Ermanto Fahamsyah, 2021, Dua Dekade Penegakan Hukum Persaingan: Perdebatan dan Isu yang Belum Terselesaikan, (Jakarta: Komisi Pengawas Persaingan Usaha), hal. 538.

[17] Budi L. Kagramanto, Implementasi UU No. 5 Tahun 1999 Oleh KPPU, Jurnal Ilmu Hukum Yustisia, Vol, No, 2007, hal. 2.

[18] Jimly Asshidiqie dalam Andi Fami Lubis, dkk, 2009, Hukum Persaingan Usaha: Antara Teks dan Konteks, Komisi Pengawas Persaingan Usaha, Jakarta, hal. 313.

[19] https://kppu.go.id/blog/2020/11/peran-kppudalam-pengawasan-kemitraan-2/ , akses 30 September 2021.

[20] Yohana Artha Uly https://money.kompas.com/read/2020/12/30/21380 0626/2020-kppu-sumbang-penerimaan-negara-rp35-9-miliar-dari-kasus-persaingan-usaha?page $=$ all, akses pada 30 September 2021.

[21] Catatan Kinerja KPPU di Tahun 2020 https://kppu.go.id/blog/2020/12/catatan-kinerjakppu-di-tahun-2020/

[22] Peraturan Menteri Agraria dan Tata Ruang/ Kepala BPN Nomor 7 Tahun 2017 Tentang Pengaturan dan Tata Cara Penetapan Hak Guna Usaha, Pasal 40 Ayat 1 huruf k.

[23] Komisi Pengawas Persaingan Usaha, Evaluasi Kebijakan Perkebunan Kelapa Sawit, hal. 21, dilihat pada http://web1.kppu.go.id/wpcontent/uploads/2020/03/Position-Paper-Sawit.pdf , akses 30 September 2021.

[24] Rejeki, S., \& Ninik, M. C. Perbedaan Budaya Dan Adaptasi Antarbudaya Dalam Relasi Kemitraan Inti-Plasma. Jurnal Ilmu Komunikasi, 4(2), 101738

[25] Ardiansyah, R., \& Aulawi, H. (2019). Identifikasi Faktor-Faktor Kunci Keberhasilan Pola Kemitraan Inti Plasma. Jurnal Kalibrasi, 17(2), 43-51. 
[26] Zahri, Imron (2013), Gagasan Mengatasi Masalah Ekonomi Rumah Tangga Petani Dalam Kemitraan Inti-Plasma Pola Pir Kelapa Sawit. In: Prosiding Seminar Nasional Perhepi Kemitraan Dalam Pengembangan Agribisnis Berbasis Sumberdaya Lokal. Perhimpunan Ekonomi Pertanian Indonesia (PERHEPI), 2013, Palembang, 15 April 2013, pp. 36-41. ISBN 978-979-8420-13-9 